\title{
Bio-priming Seed Treatment for Biological Control of Pythium ultimum Preemergence Damping-off in sh2 Sweet Corn
}

\author{
NANCY W. CALlAN, Associate Professor, Western Agricultural Research Center, Montana State University, \\ Corvallis 59828; D. E. MATHRE, Professor, Department of Plant Pathology, Montana State University, Bozeman \\ 59717; and JAMES B. MILLER, Research Technician, Western Agricultural Research Center, Montana State \\ University, Corvallis 59828
}

\begin{abstract}
Callan, N. W., Mathre, D. E., and Miller, J. B. 1990. Bio-priming seed treatment for biological control of Pythium ultimum preemergence damping-off in sh2 sweet corn. Plant Dis. 74:368372 .

Sweet corn (Zea mays) with the sh2 gene for enhanced sugar content is highly susceptible to preemergence damping-off, caused primarily by Pythium ultimum in Montana's Bitterroot Valley. Rhizosphere bacteria that adhered to hyphae of $P$. ultimum and were antagonistic to the growth of this pathogen were isolated from Bitterroot Valley soils. An isolate of Pseudomonas fluorescens, AB254, provided superior seed protection from Pythium dampingoff in naturally infested soils. At least $1 \times 10^{7} \mathrm{cfu}$ per seed of AB254 was needed to achieve maximum protection. In a process we have termed "bio-priming," dry seed was coated with $P$. fluorescens AB254 and allowed to imbibe water under warm temperatures until a 35-40\% moisture content was achieved. During bio-priming, bacterial populations increased from 10 to over 10,000-fold, depending on initial inoculum level. Bio-priming provided protection against damping-off as good as or better than seed treatment with metalaxyl when the seeds were planted in cold soil. This process may be of interest and value to growers who wish to plant sweet corn or other temperature-sensitive crops into cold soils where damping-off is a problem and the use of chemical seed treatments is not desired.
\end{abstract}

Sweet corn (Zea mays L.) carrying the shrunken-2 (sh2) gene for elevated sweetness is becoming increasingly popular with consumers. This genotype, however, is characterized by poor stands and low seedling vigor in comparison with standard sweet corn. Stand failure in $s h 2$ sweet corn has been associated with susceptibility to preemergence damping-off caused by Pythium spp., especially when seeds are planted in cold soil (11).

Seed of sweet corn, like that of several other warm-season crops such as snap beans (Phaseolus vulgaris L.), lima beans (P. limensis Macf.), soybeans (Glycine max (L.) Merr.), chickpeas (Cicer arietinum L.), and cotton (Gossypium hirsutum L.), is subject to imbibitional chilling injury, a physiological disorder that occurs when water uptake begins under low temperature $(6,8,14)$. Membrane damage during low temperature imbibition has been postulated as the mechanism involved (2).

Various substances, including soluble carbohydrates, potassium ions (26), and proteins (29), are released from sweet corn seeds upon imbibition. A high level of electrolyte leakage from sweet corn seed has been found to be an indication

Contribution from the Montana Agricultural Experiment Station, Journal Series 2364.

Accepted for publication 29 November 1989 (submitted for electronic processing).

๑ 1990 The American Phytopathological Society of low seed vigor $(28,30)$. The amount of seed exudation during germination was directly related to the incidence of damping-off in beans $(23,24)$, soybeans (17), cucumbers (Cucumis sativus L.), and peas (Pisum sativum L.) (7). Increased exudation of metabolites is characteristic of seeds germinating in cold soil (13).

In addition to abundant seed exudation, sh2 sweet corn has structural features that predispose the seed to pathogen attack. The sh 2 seed commonly has large air spaces between the pericarp and the aleurone layer. This allows pericarp breakage (26), which has resulted in increased Pythium damping-off in peas (25). Also, the small seed size of the sh2 genotype provides less nutrient reserve for the developing embryo (29).

The most practical method of controlling Pythium damping-off is by chemical, physiological, or biological seed treatment. To overcome imbibitional injury of sh2 corn, hydrating presown seed (4) and osmotic conditioning or osmopriming (5) have been recommended. Osburn and Schroth $(21,22)$ found that osmopriming of sugar beet (Beta vulgaris L.) seed protected it from attack by Pythium spp. A combination of seed hydration (solid matrix priming) and treatment of cucumber and tomato (Lycopersicon esculentum Mill.) seeds with Enterobacter cloacae (Jordan) Hormaeche and Edwards or Trichoderma spp. reduced Pythium damping-off and enhanced seedling growth (12).
Biological seed treatments may not provide adequate seed protection under all conditions. The applied bioprotectant may fail to establish on the seed or in the rhizosphere at sufficient levels for disease control because of unfavorable soil temperature, $\mathrm{pH}$, or moisture. Furthermore, biological control may be difficult to achieve with seeds releasing high levels of exudates during germination (20). A biological seed protection system that addresses problems of seed physiology, such as imbibitional chilling, would appear to have a greater potential for seed protection under adverse germination conditions.

Our objectives were to isolate one or more naturally occurring rhizobacteria that could be applied to sh 2 sweet corn seeds for protection from Pythium preemergence damping-off and to develop a delivery system that would provide consistent control of this disease in cold soil. Using the strategy of Harman and Taylor (12), we have integrated biological and physiological disease control into a system we term "bio-priming." In biopriming, temperature and moisture conditions during seed imbibition are optimized to eliminate imbibitional chilling injury (4) while a bacterial bioprotectant becomes established on the seed. Biopriming differs from osmopriming in that water uptake is regulated through adjustments in temperature, duration, and water quantity rather than by the use of an osmotic solution.

\section{MATERIALS AND METHODS}

Isolation and characterization of potential seed bioprotectants. An isolation procedure was designed to identify rhizosphere bacteria having an apparent affinity for hyphae of Pythium spp. Isolates of Pythium ultimum Trow were obtained from infected corn seeds planted at the Western Agricultural Research Center (WARC), Corvallis, Montana. Cultures were maintained on cornmeal agar (CMA).

To obtain a broad spectrum of rhizobacteria with potential as seed protectants, soils were sampled from 10 locations in the Bitterroot Valley in western Montana. Flats of each soil were sown with seeds of sh2 sweet corn (cv. Crisp'n'Sweet 710) and incubated at 25 $\mathrm{C}$ for $96 \mathrm{hr}$. After removal of the larger 
soil particles and the coleoptile, each seedling with adhering seed remnant was placed in a 5-ml sterile water blank. Plugs of $P$. ultimum ( $2 \mathrm{~mm}$ diam.) were incubated for $48 \mathrm{hr}$ at $25 \mathrm{C}$ in small culture dishes containing $3 \mathrm{ml}$ of cornmeal broth (CMB) (9). The resultant mycelial mats were then transferred individually to the tubes containing seedlings, shaken thoroughly, and incubated for $16 \mathrm{hr}$ at $25 \mathrm{C}$. Mycelial mats were removed, rinsed in sterile water, and sonicated for $5 \mathrm{~min}$ in $100 \mathrm{ml}$ of sterile water to release any attached bacteria. Serial dilutions were plated on CMA, potato-dextrose agar (PDA), or onetenth-strength tryptic soy agar (TSA) (Difco) and incubated at $25 \mathrm{C}$ for $96 \mathrm{hr}$, when individual colonies were selected. The selected isolates were streaked, six per plate, around the edge of PDA plates, and a $2-\mathrm{mm}$ plug of $P$. ultimum was placed in the center of each plate. After $36 \mathrm{hr}$, plates were examined for a zone of inhibition around the bacterial colony or for apparent lysis of hyphae in the area of contact. Selected isolates were grown for $24 \mathrm{hr}$ in $3.5 \mathrm{ml}$ of King's medium B, after which $2 \mathrm{ml}$ of $80 \%$ glycerol was added and cultures were stored at $-5 \mathrm{C}$ until further testing (D. Sands, personal communication).

Inhibition of fungal growth. Liquid cultures containing mycelial mats were used to assess the ability of selected bacteria to inhibit the growth of $P$. ultimum in vitro $(10,20)$. $P$. ultimum was grown from CMA plugs ( $2 \mathrm{~mm}$ diam.) for 16 $\mathrm{hr}$ at $18-20 \mathrm{C}$ in individual $12 \times 50 \mathrm{~mm}$ culture dishes containing $4 \mathrm{ml}$ of CMB. The resultant mycelial mats showing uniform growth (6 $\mathrm{mm}$ diam.) were inoculated with $0.1 \mathrm{ml}$ of a 48 -hr-old (25 C) nutrient broth (BBL, Cockeysville, MD) culture of selected bacterial isolates (three or four replicates per bacterium). The diameter of the mycelial mat was measured after 24 and $48 \mathrm{hr}$ and compared with cultures without bacteria. Mycelial mats were then removed from the culture dishes, blotted on paper towels, and plated on acidified CMA (1 $\mathrm{ml}$ of $25 \%$ lactic acid $1^{-1}$ ). After $24 \mathrm{hr}$, mats were checked for mycelial growth. Bacteria that severely limited or prevented growth of $P$. ultimum were tested further as seed protectants.

Greenhouse tests. Three greenhouse trials involving 52 bacterial isolates were used to further delimit potential bioprotectants for field testing. Bacterial isolates were grown on PDA for $48 \mathrm{hr}$ at $25 \mathrm{C}$. One plate of each isolate was scraped into $4 \mathrm{ml}$ of $1.5 \%$ methylcellulose (MC), medium viscosity. Sixty seeds of Crisp'n'Sweet 710 corn $(97 \%$ germination), previously surface-disinfested for 5 min in $0.25 \% \mathrm{NaOCl}$, were coated with the bacterial suspension and allowed to dry for $20 \mathrm{hr}$ (16). Twelve seeds were planted $2 \mathrm{~cm}$ deep in one row of a 72 cell flat in a randomized complete block design with four replications. Flats contained field soil from WARC, a Burnt Fork Sandy Loam naturally infested with 1,000 propagules $\mathrm{g}^{-1}$ of Pythium spp., primarily $P$. ultimum, with $5.6 \mathrm{ppm}$ $\mathrm{Fe}$ and a $\mathrm{pH}$ of 7.4. Populations of Pythium spp. were determined by the method of Ali-Shtayeh et al (1). Each trial included surface-disinfested, nontreated seeds and seeds treated with MC, metalaxyl ( $0.3 \mathrm{~g}$ a.i. $\mathrm{kg}^{-1}$ seed $)$, captan (1.0 g a.i. $\mathrm{kg}^{-1}$ seed), or diazinon (1.4 g a.i. $\mathrm{kg}^{-1}$ seed). Previous testing had determined that a 5-min treatment with $0.25 \% \mathrm{NaOCl}$ had no effect on seed germination. Untreated seed was also sown into pasteurized soil. Soil temperature averaged $23-27 / 7 \mathrm{C}(\mathrm{max} / \mathrm{min})$.

Field testing of bacterial isolates. The nine most consistently performing isolates in the greenhouse tests were selected for further testing in the field at WARC. Four PDA plates were scraped into 16 $\mathrm{ml}$ of MC and applied to 350 sh2 sweet corn seeds (Crisp'n'Sweet 620, germination $91 \%$ ). Seed was planted by hand, $3.5 \mathrm{~cm}$ deep and $5 \mathrm{~cm}$ apart, in a randomized complete block design with six single-row replications of 50 seeds each in the first experiment (26 May 1988) and five replications in the second (22 June). Included were surface-disinfested seed treated with metalaxyl, diazinon, or MC alone and surface-disinfested nontreated seeds. Soil temperature at $5 \mathrm{~cm}$ was recorded with a thermograph. Analysis of variance was conducted on data combined over the two field experiments.

Levels of seed bacterization at planting were determined by dilution plating. Three replications of five seeds each were washed in $5 \mathrm{ml}$ of $0.1 \mathrm{M}$ phosphate buffer (pH 6.8) for $30 \mathrm{~min}$ with vortex agitation at 10 -min intervals (16). Then, $0.10 \mathrm{ml}$ of the appropriate dilution was plated on one-tenth-strength TSA, and bacterial colonies were counted after $48 \mathrm{hr}$.

Bacterization of dry seed. Crisp'n'Sweet 710 corn seed was treated with isolate AB254 of Pseudomonas fluorescens Migula suspended in MC to achieve approximately $\log _{10} 3,5,7$, and $9 \mathrm{cfu} \mathrm{seed}^{-1}$. Thirty-six seeds were planted in three rows of a 72-cell flat of naturally infested Burnt Fork Sandy Loam in a randomized complete block design with six replications. Included were surface-disinfested seed treated with metalaxyl, MC, or PCNB and surface-disinfested nontreated seed. Soil temperature averaged 12.7 $\mathrm{C}$ during the first $24 \mathrm{hr}$ and was increased to $17.5 / 12.7 \mathrm{C}(\mathrm{max} / \mathrm{min})$ for the remainder of the experiment. Emergence was tabulated daily.

Bio-priming. Bio-priming as described here combines seed bacterization with the hydration technigue of Bennett and Waters (4). Three hundred and fifty Crisp'n'Sweet 710 corn seeds $(51 \mathrm{~g})$ were coated with $P$. fluorescens AB254 in MC as described above and either allowed to dry overnight or, after drying $2 \mathrm{hr}$, placed in $51 \mathrm{~g}$ of sterile vermiculite in a self-sealing plastic bag to which $64 \mathrm{ml}$ of sterile water was added. Seeds were incubated for $22 \mathrm{hr}$ at $25 \mathrm{C}$ in the first two experiments and for $20 \mathrm{hr}$ at $22 \mathrm{C}$ in the third experiment. At the end of this period, the seed moisture content was $35-40 \%$. Seed was planted in 72-cell flats of naturally infested Burnt Fork Sandy Loam soil (700-1,000 propagules of $P$. ultimum $\mathrm{g}^{-1}$ ) as described above. Seed treated with metalaxyl, PCNB, or $\mathrm{MC}$ alone, MC-treated and nontreated hydrated seed, and surface-disinfested nontreated seed were also included. This experiment was conducted three times with similar results. Greenhouse soil temperature was adjusted to approximately $11-13 \mathrm{C}$ for the first $20-24 \mathrm{hr}$, then raised to $17-18 / 11-13 \mathrm{C}(\max / \mathrm{min})$ for the remainder of each experiment.

Soil iron content and pH. A greenhouse trial was conducted to examine the ability of $P$. fluorescens AB254 to protect $s h 2$ corn seeds in two naturally infested soils varying in iron content and $\mathrm{pH}$. The Burnt Fork Sandy Loam soil described above was compared with a Bass Coarse Sandy Loam soil having $35.3 \mathrm{ppm} \mathrm{Fe}$, a $\mathrm{pH}$ of 6.6 , and a mean of 300 propagules $\mathrm{g}^{-1}$ of $P$. ultimum. Seeds of Crisp'n'Sweet 710 were bio-primed as above, and six replications of 36 seeds each were planted in a randomized complete block design. Surface-disinfested seeds treated with metalaxyl, PCNB, or $\mathrm{MC}$ alone were also included. Soil temperature averaged $10.8 \mathrm{C}$ for the first $20 \mathrm{hr}$, increasing to $18.6 / 10.8 \mathrm{C}(\max /$ min) during emergence. Seedling height to the top of the first leaf was measured at 21 days.

\section{RESULTS}

Bioprotectant screening. Because $P$. ultimum was isolated consistently from sh2 sweet corn seed planted in naturally infested field soil and because metalaxyl provided good protection against damping-off under such conditions, we directed our efforts toward rhizobacteria that were antagonistic toward this pathogen. The lack of control provided by the insecticide diazinon or the fungicide PCNB suggested that neither insects nor fungi other than Pythium spp. were involved in problems of seedling emergence. Of approximately 1,300 bacterial isolates used to challenge $P$. ultimum on PDA, 247 produced a zone of inhibition and 61 caused a degradation and vacuolation of hyphal cytoplasm. Of these 308 isolates, 96 caused the mycelial mat to cease growth and 18 showed fungicidal activity, i.e., the mycelial mat did not grow when plated on one-tenth-strength CMA. Of the 47 isolates that were involved in all three greenhouse trials, 19 significantly increased emergence over the nontreated control in two of three trials and nine did so in all three. The most effective and consistently per- 
forming isolate, $\mathrm{AB} 254$, was identified as $P$. fluorescens.

When the nine most effective isolates from the greenhouse trials were applied to field-planted seed, $P$. fluorescens AB254 provided significant seed protection when compared with the surfacedisinfested control and the other eight isolates (Table 1). In the May experiment, which was conducted in cold soil, $P$. fluorescens AB254 provided less protection than did the metalaxyl treatment.

Bacterial populations on dry seed. When applied to dry seed, $5.1 \log _{10}$ cfu seed $^{-1}$ of $P$. fluorescens AB254 increased

Table 1. Biocontrol of preemergence damping-off, caused by Pythium ultimum, of sh2 sweet corn by treatment of dry seed with nine bacterial isolates under natural field conditions ${ }^{\mathrm{x}}$

\begin{tabular}{lccc}
\hline & \multicolumn{3}{c}{ Emergence (\%) $^{\mathbf{y}}$} \\
\cline { 2 - 4 } Treatment & 26 May 1988 & 22 June 1988 & Average \\
\hline Metalaxyl $^{\mathbf{z}}$ & 77.7 & 86.0 & $81.5 \mathrm{a}$ \\
AB254 & 28.0 & 76.4 & $52.8 \mathrm{~b}$ \\
AB288 & 10.3 & 69.6 & $40.1 \mathrm{c}$ \\
AB166 & 7.7 & 71.6 & $40.0 \mathrm{c}$ \\
AB223 & 4.0 & 71.2 & $37.7 \mathrm{~cd}$ \\
AB302 & 4.3 & 70.8 & $37.5 \mathrm{~cd}$ \\
AB142 & 3.0 & 70.0 & $36.6 \mathrm{~cd}$ \\
AB267 & 3.7 & 66.0 & $35.3 \mathrm{~cd}$ \\
Carrier alone & 2.8 & 63.2 & $33.0 \mathrm{~cd}$ \\
AB268 & 3.3 & 58.8 & $30.8 \mathrm{de}$ \\
AB281 & 4.0 & 56.0 & $30.0 \mathrm{de}$ \\
Disinfested control & 1.7 & 48.8 & $25.3 \mathrm{e}$ \\
\hline
\end{tabular}

${ }^{x}$ Planted in Burnt Fork Sandy Loam naturally infested with $P$. ultimum (700-1,000 propagules $\left.\mathrm{g}^{-1}\right)$. Soil temperature at $5 \mathrm{~cm}$ averaged $23.4 / 8.6 \mathrm{C}(\mathrm{max} / \mathrm{min})$ during the 10 days following the 26 May planting and $30 / 14 \mathrm{C}$ following the 22 June planting. Seed was coated with bacteria (6.9-8.8 $\left.\log _{10} \mathrm{cfu}^{-1} \mathrm{sed}^{-1}\right)$ in $1.5 \%$ methylcellulose and dried overnight.

${ }^{y}$ Values are the means of six (26 May) or five (22 June) replications of 50 seeds each. Means within a column followed by different letters are significantly different $(P \leq 0.05)$ according to Student-Newman-Keuls multiple range test. Factorial ANOVA conducted on the arcsin of the square root of the proportion.

${ }^{z}$ Applied at $0.3 \mathrm{~g}$ a.i. $\mathrm{kg}^{-1}$ seed.

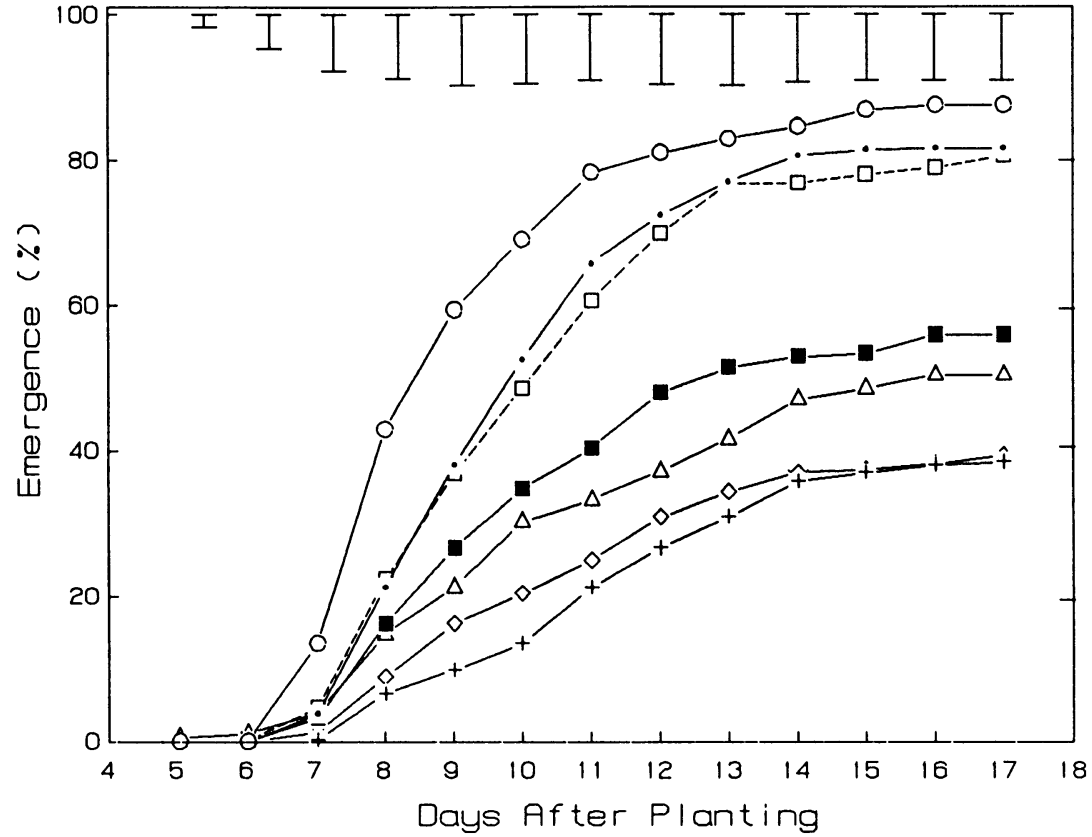

Fig. 1. Biological control of preemergence damping-off, caused by Pythium ultimum, of sh2 corn by application of Pseudomonas fluorescens AB254 to dry seed. Seed coated with a methylcellulose suspension of $8.9 \log _{10}(\bullet), 7.4 \log _{10}(\square), 5.1 \log _{10}(\square), 3.7 \log _{10}(\triangle)$, metalaxyl $(\bigcirc)$, PCNB $(+)$, methylcellulose $(\diamond)$. Bars $=$ protected LSD $(P=0.05)$. seed was considerably less effective than bio-priming with this organism. Low temperature imbibition increased the severity of this test, as indicated by the poor emergence of metalaxyl-treated seed and the increase in emergence after seed hydration alone.

During bio-priming, bacterial populations on seed rose substantially, with the magnitude of increase apparently dependent on initial inoculum level. For example, in various experiments, initial populations of $2.9,4.9,6.8,7.4$, and 8.9 $\log _{10} \mathrm{cfu} \mathrm{seed}^{-1}$ increased to $6.8,7.0,7.6$, 8.2 , and $9.2 \log _{10}$ cfu seed $^{-1}$, respectively, after bio-priming. This indicates that relatively low seed treatment bioprotectant levels may be relied on to increase to effective populations during the biopriming process.

Bio-primed seed emerged at a more rapid rate than did metalaxyl-treated seed (Fig. 2). Seed hydration with no additional treatment improved emergence compared with that of MC-treated or nontreated seed, but to a lesser extent than did bio-priming or metalaxyl. Seed hydrated after treatment with MC emerged at a higher rate than seed hydrated after only surface-disinfestation.

Soil iron content and pH. Bio-priming with P. fluorescens AB254 and metalaxyl treatment were equally effective in controlling Pythium preemergence damping-off in soil of high or low iron content and of slightly different $\mathrm{pH}$ level (Table 3). Emergence was low in either soil when

Table 2. Bio-priming of sh2 sweet corn for control of damping-off, caused by Pythium ultimum, in naturally infested soil under cold greenhouse conditions ${ }^{t}$

\begin{tabular}{lc}
\hline \hline Treatment & Emergence (\%) $^{\mathrm{u}}$ \\
\hline AB254 bio-primed & \\
Metalaxyl $^{\mathrm{v}}$ & $39.4 \mathrm{a}$ \\
Hydrated only $^{\mathrm{x}}$ & $30.1 \mathrm{~b}$ \\
AB254 seed bacterization $^{\mathrm{y}}$ & $19.8 \mathrm{c}$ \\
PCNB $^{\mathrm{z}}$ & $8.3 \mathrm{~d}$ \\
Disinfested control $^{\text {Methylcellulose }}$ & $1.4 \mathrm{~d}$ \\
Methe & $1.0 \mathrm{~d}$ \\
\end{tabular}

${ }^{t}$ Planted in Burnt Fork Sandy Loam. Soil temperature during the first $24 \mathrm{hr}$ averaged $10.8 \mathrm{C}$ and during emergence, $17.5 / 13.0 \mathrm{C}$ $(\max / \mathrm{min})$.

"Values are the untransformed means of six replications of 36 seeds each. ANOVA conducted on the arcsin of the square root of the proportion. Means within a column followed by different letters are significantly different $(P \leq 0.05)$ according to StudentNewman-Keuls multiple range test.

${ }^{v}$ Pseudomonas fluorescens isolate AB254 applied in $1.5 \%$ methylcellulose; 350 seeds incubated with $51 \mathrm{~g}$ of vermiculite and 64 $\mathrm{ml}$ of water for $22 \mathrm{hr}$ at $25 \mathrm{C}$. AB254 population was $9.2 \log _{10} \mathrm{cfu}^{-1}$ seed $^{-1}$ at planting.

${ }^{\mathrm{w}}$ Applied at $0.3 \mathrm{~g}$ a.i. $\mathrm{kg}^{-1}$ seed.

${ }^{\mathrm{x}}$ Seeds incubated in moist vermiculite as above.

${ }^{y}$ AB254 applied in $1.5 \%$ methylcellulose and allowed to air-dry. AB254 population was $8.5 \log _{10}$ cfu seed $^{-1}$ at planting.

${ }^{\mathrm{z}}$ Applied at $1.875 \mathrm{~g}$ a.i. $\mathrm{kg}^{-1}$ seed. 


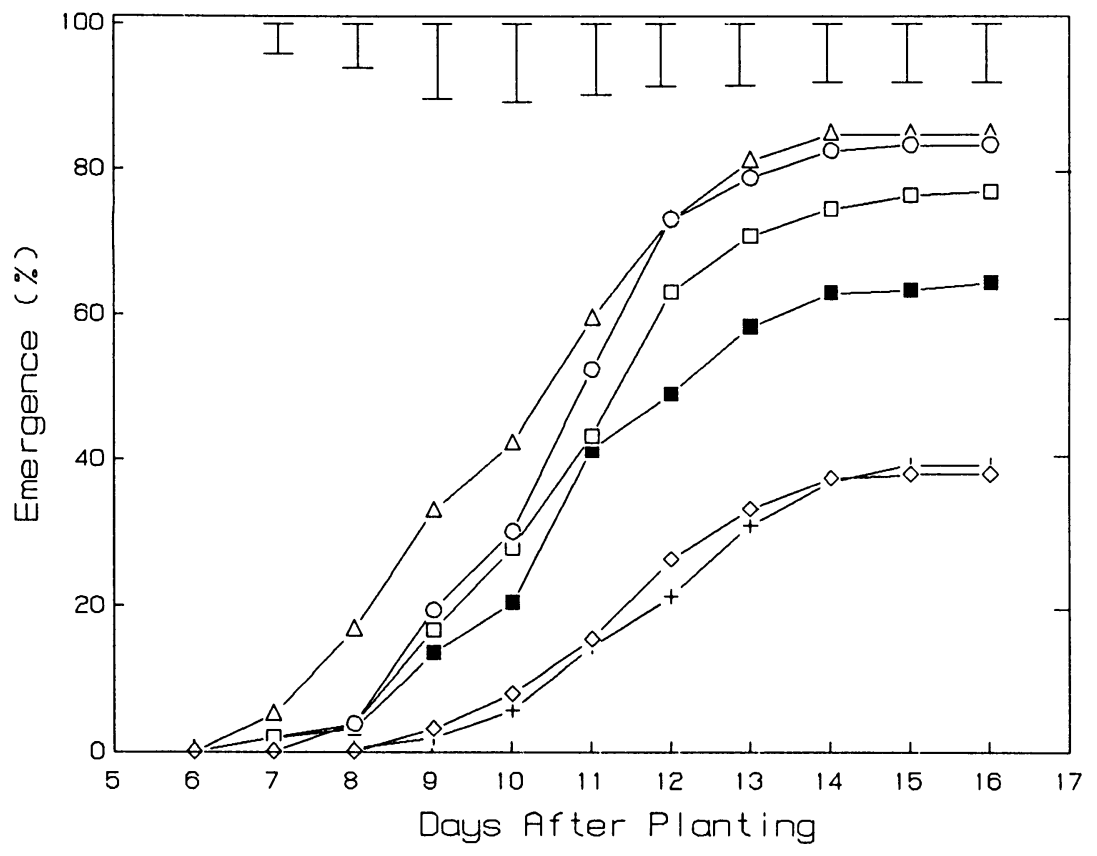

Fig. 2. Control of preemergence damping-off, caused by Pythium ultimum, of sh2 corn by bio-priming with Pseudomonas fluorescens AB254. Bio-primed $(\triangle)$, metalaxyl $(O)$, methylcellulose-coat hydrated $(\square)$, nontreated hydrated $(\square)$, PCNB $(+)$, methylcellulose $(\diamond)$. Bars $=$ protected $\operatorname{LSD}(P=0.05)$.

seeds were untreated or treated with PCNB. Seedling growth in infested soil was increased by either bio-priming or metalaxyl treatment. There was no interaction $(P \leq 0.05)$ between seed treatment and soil type.

\section{DISCUSSION}

Various isolates of $P$. fluorescens have been found to be effective seed bioprotectants against Pythium spp. in a number of crop species $(15,18,27,31)$. The Bitterroot Valley isolate of $P$. fluorescens, $\mathrm{AB} 254$, was effective in protecting sh2 sweet corn against Pythium preemergence damping-off under a range of soil conditions and temperatures, as evidenced by the control it provided during various times of the year. Bacterization with $P$. fluorescens AB254 had no effect on final emergence of seed planted in pasteurized soil compared with nontreated seed (unpublished), indicating that this organism per se is neither germination promotive nor phytotoxic.

The high levels of nutrient exudation by $s h 2$ corn seeds during imbibition provide a challenge to biocontrol of seedrotting pathogens. Nelson et al $(19,20)$ found that seeds of species that produced very little exudate during imbibition were more effectively protected by $E$. cloacae than those that released abundant exudate. P. fluorescens AB254 may be able to defend the $s h 2$ sweet corn spermoplane against attack by Pythium spp. by monopolizing this abundant nutrient source (10), by competing for iron through siderophore release $(3,18)$, or by antibiotic production (15). P. fluorescens
AB254 protected seeds equally well in soil with high or low iron content, which may indicate that iron-mediated siderophore content is not an essential component of seed protection. However, further investigation of the mode of action of $P$. fluorescens AB254 in seed protection is needed.

Bio-priming with $P$. fluorescens AB254 enhanced the ability of this biocontrol agent to protect sh2 corn seeds from attack by Pythium spp. in cold to warm soils. The effects of biopriming on both seed physiology to relieve chilling injury and bacterial growth to provide pathogen control may be involved in this response.

Seed hydration improved seedling emergence over that with nontreated seed but did not provide protection equal to either bio-priming or treatment with metalaxyl. This is in contrast to results presented by Osburn and Schroth (22), who found that osmopriming protected sugar beet seeds from Pythium dampingoff as well as did treatment with metalaxyl. The relative effectiveness of hydration alone in seed protection may depend on crop species, soil temperature, and the level of disease pressure.

Because of the rapidity of seed attack by Pythium spp. (24), establishment of the bioprotectant on the seed before planting, i.e., during bio-priming, was undoubtedly an important aspect of protection. We found that under field conditions, colonization of nontreated sh2 corn by $P$. ultimum was extensive $24 \mathrm{hr}$ after planting and nearly total by $48-72$ $\mathrm{hr}$, depending on soil temperature (unpublished). The value of bio-priming
Table 3. Influence of soil iron content on control of preemergence damping-off, caused by Pythium ultimum, and growth of $s h 2$ corn by bio-priming with Pseudomonas fluorescens $\mathrm{AB} 254^{\mathrm{u}}$

\begin{tabular}{lcc}
\hline \hline Treatment & $\begin{array}{c}\text { Emergence } \\
(\%)\end{array}$ & $\begin{array}{c}\text { Height }^{\mathrm{v}} \\
\text { (cm) }\end{array}$ \\
\hline Soil iron content & & \\
$\quad 35.3 \mathrm{ppm}$ & $64.7 \mathrm{a}^{\mathrm{w}}$ & $3.9 \mathrm{a}$ \\
$\quad 5.6 \mathrm{ppm}$ & $61.3 \mathrm{a}$ & $3.1 \mathrm{~b}$ \\
Seed treatment & & \\
$\quad$ Metalaxyl & $85.0 \mathrm{a}$ & $4.0 \mathrm{a}$ \\
AB254 bio-primed $^{\mathrm{y}}$ & $84.7 \mathrm{a}$ & $4.3 \mathrm{a}$ \\
PCNB $^{\mathrm{z}}$ & $42.1 \mathrm{~b}$ & $3.0 \mathrm{~b}$ \\
Methylcellulose $^{\mathrm{x}}$ & $40.3 \mathrm{~b}$ & $2.9 \mathrm{~b}$ \\
\hline
\end{tabular}

"Planted in Burnt Fork Sandy Loam naturally infested with $P$. ultimum, pH 7.4 (5.6 ppm Fe), or in Bass Coarse Sandy Loam, pH 6.6 (35.3 ppm Fe). Soil temperature averaged $10.8 \mathrm{C}$ during the first $20 \mathrm{hr}$, then $18.6 / 10.8 \mathrm{C}(\mathrm{max} / \mathrm{min})$. Values are the untransformed means of six replications of 36 seeds each and are averaged across the four seed treatments or both iron contents. Factorial ANOVA conducted on the arcsin of the square root of the final germination proportion. The interactions were nonsignificant.

${ }^{v}$ Seedling height to the top of the first leaf at 21 days.

${ }^{\mathrm{w}}$ Column means (within treatments) followed by the same letter are not significantly different $(P \leq 0.05)$ according to StudentNewman-Keuls multiple range test.

${ }^{\mathrm{x}}$ Applied at $0.3 \mathrm{~g}$ a.i. $\mathrm{kg}^{-1}$ seed.

${ }^{y}$ AB254 applied in $1.5 \%$ methylcellulose; 9.2 $\log _{10}$ cfu seed ${ }^{-1}$ after bio-priming.

${ }^{2}$ Applied at $1.875 \mathrm{~g}$ a.i. $\mathrm{kg}^{-1}$ seed.

over that of seed bacterization alone was clearly seen when the seed was planted in cold soil.

Bio-priming can provide a high level of protection against preemergence damping-off of sh2 sweet corn seed caused by $P$. ultimum. This seed treatment appears to be especially effective when seed is planted in cold soil. Protection by bio-priming was generally equal or superior to the control provided by metalaxyl. As such, it may be of interest and value to growers who want to grow the supersweet corns in areas where planting conditions involve cold soils and to growers who wish to avoid chemical treatment of their seed.

\section{ACKNOWLEDGMENTS}

We thank D. C. Sands and Alice Pilgeram for identifying Pseudomonas fluorescens AB254 and Crookham Co., Caldwell, Idaho, for donating seed.

\section{LITERATURE CITED}

1. Ali-Shtayeh, M. S., Lim-Ho, C. L., and Dick, M. W. 1986. An improved method and medium for quantitative estimates of populations of Pythium species from soil. Trans. Br. Mycol. Soc. 86:39-47.

2. Basra, A. J., Bedi, S., and Malik, C. P. 1988. Accelerated germination of maize seeds under chilling stress by osmotic priming and associated changes in embryo phospholipids. Ann. Bot. 61:635-639.

3. Becker, J. O., and Cook, R. J. 1988. Role of siderophores in suppression of Pythium species and production of increased-growth response of 
wheat by fluorescent pseudomonads. Phytopathology 78:778-782.

4. Bennett, M. A., and Waters, L., Jr. 1987. Germination and emergence of high-sugar sweet corn is improved by presowing hydration of seed. HortScience 22:236-238.

5. Bradford, K. J. 1986. Manipulation of seed water relations via osmotic priming to improve germination under stress conditions. HortScience 2:1105-1112.

6. Cal, J. P., and Obendorf, R. L. 1972. Imbibitional chilling injury in Zea mays L. altered by initial kernel moisture and maternal parent. Crop Sci. 12:369-373.

7. Chen, W., Hoitinck, H. A. J., Schmitthenner, A. F., and Tuovinen, O. H. 1988. The role of microbial activity in suppression of damping off caused by Pythium ultimum. Phytopathology 78:314-322.

8. Cohn, M. A., and Obendorf, R. L. 1976. Independence of imbibitional chilling injury and energy metabolism in corn. Crop Sci. 16:449452.

9. Dhingra, O. D., and Sinclair, J. B. 1985. Basic Plant Pathology Methods. CRC Press, Boca Raton, FL. 355 pp.

10. Elad, Y., and Chet, I. 1987. Possible role of competition for nutrients in biocontrol of Pythium damping-off by bacteria. Phytopathology 77:190-195.

11. Guzman, V. L., Wolf, E. A., and Martin, F G. 1983. Effect of compensated-rate seeding and seed protectants on yield and quality of a shrunken-2 sweet corn hybrid. HortScience 18:338-340.

12. Harman, G. E., and Taylor, A. G. 1988. Improved seedling performance by integration of biological control agents at favorable $\mathrm{pH}$ levels with solid matrix priming. Phytopathology
78:520-525.

13. Hayman, D. S. 1969. The influence of temperature on the exudation of nutrients from cotton seeds and on pre-emergence damping-off by Rhizoctonia solani. Can. J. Bot. 47:1663-1669.

14. Herner, R. C. 1986. Germination under cold soil conditions. HortScience 21:1118-1122.

15. Howell, C. R., and Stipanovic, R. D. 1980 Suppression of Pythium ultimum-induced damping-off of cotton seedlings by Pseudomonas fluorescens and its antibiotic, pyoluteorin. Phytopathology 70:712-715.

16. Juhnke, M. E., Mathre, D. E., and Sands, D. C. 1987. Identification and characterization of rhizosphere-competent bacteria of wheat. Appl. Environ. Microbiol. 53:2793-2799.

17. Keeling, B. L. 1974. Soybean seed rot and the relation of seed exudate to host susceptibility. Phytopathology 64:1445-1447.

18. Loper, J. E. 1988. Role of fluorescent siderophore production in biological control of Pythium ultimum by a Pseudomonas fluorescens strain. Phytopathology 78:166-172.

19. Nelson, E. B. 1988. Biological control of Pythium seed rot and preemergence dampingoff of cotton with Enterobacter cloacae and Erwinia herbicola applied as seed treatments. Plant Dis. 72:140-142.

20. Nelson, E. B., Chao, W. L., Norton, J. M., Nash, G. T, and Harman, G. E. 1986. Attachment of Enterobacter cloacae to hyphae of Pythium ultimum: Possible role in the biological control of Pythium preemergence damping-off. Phytopathology 76:327-335.

21. Osburn, R. M., and Schroth, M. N. 1988. Effect of osmopriming sugar beet seed on exudation and subsequent damping-off caused by Pythium ultimum. Phytopathology 78:1246-1250.

22. Osburn, R. M., and Schroth, M. N. 1989. Effect of osmopriming sugar beet seed on germination rate and incidence of Pythium ultimum damping-off. Plant Dis. 73:21-24.

23. Schroth, M. N., and Cook, R. J. 1964. Seed exudation and its influence on pre-emergence damping-off of bean. Phytopathology 54:670 673.

24. Stanghellini, M. E., and Hancock, J. G. 1971. Radial extent of the bean spermosphere and its relation to the behavior of Pythium ultimum. Phytopathology 61:165-168.

25. Stasz, T. E., Harman, G. E., and Marx, G. A 1980. Time and site of infection of resistant and susceptible germinating pea seeds by Pythium ultimum. Phytopathology 70:730-733.

26. Styer, R. C., and Cantliffe, D. J. 1983. Changes in seed structure and composition during development and their effects on leakage in two endosperm mutants of sweet corn. J. Am. Soc. Hortic. Sci. 108:721-728.

27. Suslow, T. V., and Schroth, M. N. 1982. Rhizobacteria of sugar beets: Effects of seed application and root colonization on yield. Phytopathology 72:199-206.

28. Tracy, W. F., and Juvik, J. A. 1988. Electrolyte leakage and seed quality in a shrunken-2 maize selected for improved field emergence. HortScience 23:391-392.

29. Wann, E. V. 1986. Leaching of metabolites during imbibition of sweet corn seed of different endosperm genotypes. Crop Sci. 26:731-733.

30. Waters, L., Jr., and Blanchette, B. L. 1983. Prediction of sweet corn field emergence by conductivity and cold tests. J. Am. Soc. Hortic. Sci. 108:778-781.

31. Weller, D. M., and Cook, R. J. 1986. Increased growth of wheat by seed treatments with fluorescent pseudomonads, and implications of $P y$ thium control. Can. J. Plant Pathol. 8:328-334. 